\title{
Effect of Some Industrial Wastes onthe Physico-Chemical and Mechanical Properties of Hardened Cement Pastes
}

\author{
E. A. Kishar ${ }^{(a)}$, D. A. Ahmed ${ }^{(a)}$, T.M.ELSoukary ${ }^{(b)}$, M.R.Mohamed ${ }^{(\text {a) }}$ and S. M. Fathi ${ }^{(a)}$ \\ ${ }^{\text {(a) }}$ Faculty of women, AinShamsUniversity, Cairo, Egypt. \\ (b) Housing and Construction, Cairo, Dokie
}

\begin{abstract}
In this work, Portland cement (OPC) is replaced by different ratios of aBlast Furnace Slag, Silica Fume(SF) and Cement Kiln dust (CKD). Compressive strength, combined water and phase composition of cement are measured after $1,3,7,28,90,180,270$ and 360 days immersion in tape water.The effect of5\% magnesium sulfate solutionon curingofthe hardenedblendedcement pastes was also examined.

Such replacement modified the strength, pore structure, and permeability of the hardened cement pastes. Sulphateattack on cement paste causes a serious deterioration. The aim of this investigation is to study the physico-chemical and mechanical properties of the prepared hardened blended cement pastes as well as study the effect of magnesium sulphate attack on these pastes. In addition, the effect of replacement of OPC by some additive was examined.
\end{abstract}

Keywords:OPC, Blended Cement, Cement kiln dust (CKD), Silica fume (SF), blastfurnace slag (GBFS) and Magnesium sulfate attack.

E-mail:samar.fathi@yahoo.com 


\section{Introduction}

Cement is a binder, which can bind other materials together .The major components of Portland cement are tri- and di-calcium silicates $\left(\mathrm{C}_{3} \mathrm{~S}, \mathrm{C}_{2} \mathrm{~S}\right)$, tricalcium aluminates $\left(\mathrm{C}_{3} \mathrm{~A}\right)$ and tetra-calcium aluminate ferrates $\left(\mathrm{C}_{4} \mathrm{AF}\right)$,Svinning K.(2006).

Blended cements are made of partial replacement of ordinary Portland cement (OPC) by industrial solid wastes and by-products such as cement kiln dust (CKD), silica fume (SF), blast-furnace slag (GBFS) and burnt clay. In addition, some natural or artificial pozzolans are used as active mineral additives. In addition, limestone acts as a filler to modify the concrete properties.

The slag cement is more sulfate resistant than Portland cement. Granulatedblast-furnace slag by itself is hydraulically very weak. Due to its glassy structure, a highly alkaline medium is required in order to disintegratethe silicate-aluminates network of the slag glass; the liberated free lime during the hydration of Portland cement clinker is normally used to provide this alkalinity Abdel Rahman et al. (2011).

Pardhasaradhi .K. and Prasad G. (2016)reported thatsilicon oxide content in silica fume can react with calcium hydroxide to produce more calcium silicate hydrate $(\mathrm{CSH})$ which is a gel compound as well as reducing the amount of calcium hydroxide. Thus, this contributes to the strength of the concrete, producingstronger and denser concrete as well as enhances the durability of the concrete.

Pavia and Regan (2010) investigated the influence of cement kiln dust (CKD) on the properties of mortars made with a non-hydraulic binder of high available lime content (calcium hydroxide).They observed that the compressive strength increases with the $10 \%$ CKD.

Wang. et al. (2012)studied the effects of steel slag and GBFS on some properties of cement to put forward the theoretical basis of using steel slag and GBFS as a blended mineral admixture for concrete. Steel slag has a negative effect on the early strength as well as the late-age strength.Chen and Brouwers (2010)proposed reaction models for slag-blended cements. The models developed are based on stoechimetry calculations in order to correlate 
the chemical compositions of the unhydrated main phases (slag and cement) with the quantities of hydration products and the composition of the $\mathrm{C}-\mathrm{S}-\mathrm{H}$ formed at final hydration.

Inan(2012) examined the compressive strength and sulfate resistance of mortars containing silica fume in different replacement levels 5,10 and $15 \%$ of silica fume by weight of cement. The result showed that compressive strength values of silica fume mortars are generally lower than control mixtures up to 28 days. Beyond this age, compressive strengths of silica fume-incorporated mixtures are higher than that of control mixtures. Sulphates are mostly found in the form of sodium sulphate $\left(\mathrm{Na}_{2} \mathrm{SO}_{4}\right)$ or magnesium sulphate $\left(\mathrm{MgSO}_{4}\right)$. The cation associated with $\mathrm{SO}_{4}{ }^{-2}$ has an influence on the attack mechanism and the resulting deterioration. Sodium sulphate attack will result in expansive reaction products while magnesium sulphate attack will result in reduction in strength (Maes and De Belie(2014)).

The objective of this work is to study the effect of addition of some industrial wastes (CKD, Silica fume and Slag) toward cement pastes hydration in presence and absence of sulphatesolution.The interpretation of hydration characteristics of Portland cement and its blends with other admixture can be investigated by compressive strength, combined water (Wn \%)and porosity.The phase compositionof the formed hydrates can becharacterized by X-ray diffraction.

\section{Experimental}

\section{A. Materials:}

The materials used in this study areordinary Portland cement,OPCobtained from Toura factory, Egypt, its chemicalcomposition is given in Table (1), and its mineralogical composition $\mathrm{C}_{3} \mathrm{~S}: 58.29, \mathrm{C}_{2} \mathrm{~S}: 13.85, \mathrm{C}_{3} \mathrm{~A}: 5.84, \mathrm{C}_{4} \mathrm{AF}: 11.99$.Granulated blast-furnace slag,GBFS is obtained from Helwan Company of steal, Egypt. Its chemical composition is shown in Table (1).Cement kiln dust, CKD was obtained fromToura factory and itschemical composition is given in Table (1)also. Silica fume, SF used in this work is obtained fromferrosilicon company, kom-ombo,Egypt. Its chemical composition is also given in Table (1). The X-ray diffractograms of theusedmaterials are shown in figures (1-3). 


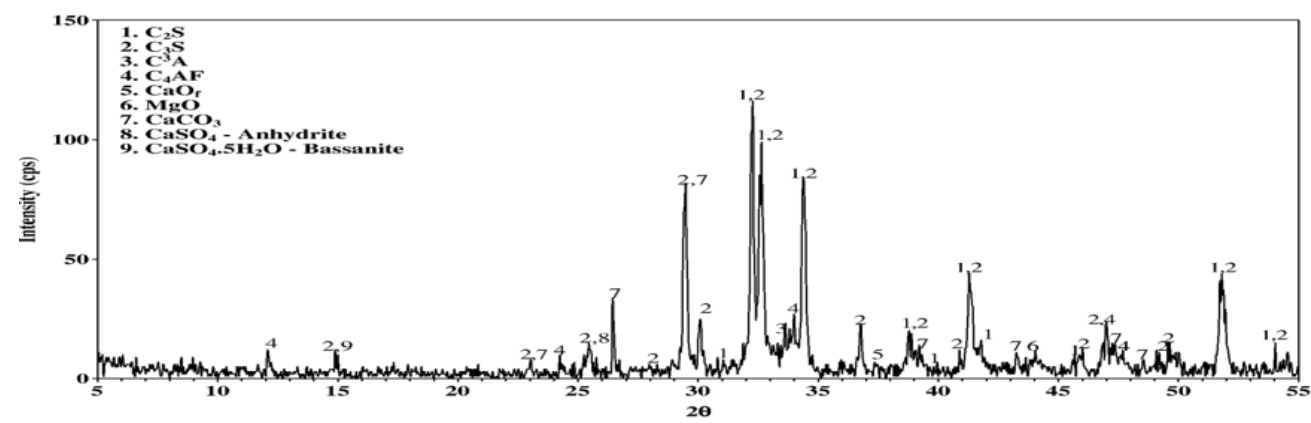

Figure1: X-ray diffraction pattern of OPC

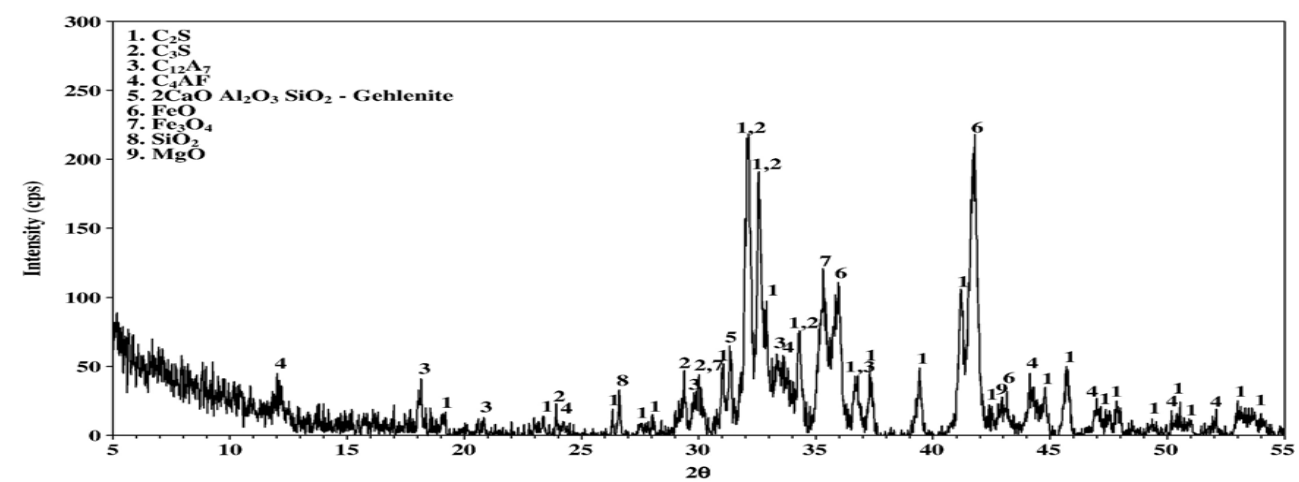

Figure 2: X-ray diffraction pattern of GBFS

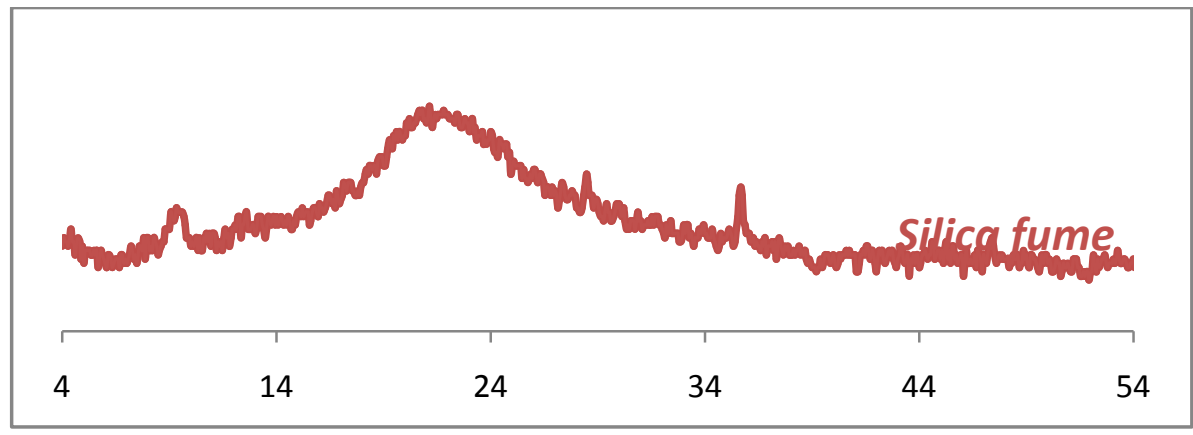

Figure 3: X-ray diffraction pattern of SF

Table (1): Chemical oxide composition of the used materials. 


\begin{tabular}{|c|c|c|c|c|}
\hline $\begin{array}{c}\text { Oxide } \\
(\%)\end{array}$ & OPC & CKD & GBFS & SF \\
\hline $\mathrm{CaO}$ & 62.90 & 46.99 & 35.56 & 0.16 \\
\hline $\mathrm{SiO}_{2}$ & 20.10 & 13.12 & 38.90 & 96.80 \\
\hline $\mathrm{Al}_{2} \mathrm{O}_{3}$ & 4.70 & 4.25 & 12.90 & 0.20 \\
\hline $\mathrm{Fe}_{2} \mathrm{O}_{3}$ & 3.90 & 1.99 & 1.75 & 0.41 \\
\hline $\begin{array}{c}\text { Ignition } \\
\text { Loss }\end{array}$ & 2.95 & 8.35 & - & 1.98 \\
\hline $\mathrm{SO}_{3}$ & 2.50 & 11.89 & 0.74 & 0.32 \\
\hline MgO & 1.70 & 2.98 & 8.62 & 0.09 \\
\hline $\begin{array}{c}\text { Insoluble } \\
\text { residue }\end{array}$ & 0.94 & - & - & - \\
\hline $\mathrm{K}_{2} \mathrm{O}$ & 0.27 & 4.59 & 0.68 & 0.04 \\
\hline $\mathrm{Cl}^{-}$ & 0.04 & 5.25 & 0.02 & - \\
\hline $\mathrm{Na}_{2} \mathrm{O}$ & - & 0.59 & 0.83 & - \\
\hline Total & 100 & 100 & 100 & 100 \\
\hline
\end{tabular}

\section{B. Preparation of cement pastes:}

\section{B.1.Preparation of dry mixes:}

The different mixes composition of the prepared samples are given in Table

(2). The ingredients of each mix are mechanically mixed for one hour in a porcelain ball mill using three balls to attain complete homogeneity then kept in airtight containers until the time of cement paste preparation.

Table (2): Mix composition.

\begin{tabular}{|c|c|c|c|c|}
\hline \multirow{2}{*}{ Mixes } & \multicolumn{4}{|c|}{ Composition \% } \\
\cline { 2 - 5 } & OPC & CKD & GGBFS & SF \\
\hline M $_{0}$ & 100 & - & - & - \\
\hline MIA & 50 & 5 & 45 & - \\
\hline MIB & 50 & 5 & 40 & 5 \\
\hline MIC & 50 & 5 & 35 & 10 \\
\hline MID & 50 & 5 & 25 & 20 \\
\hline
\end{tabular}

\section{B.2. Mixing of cement pastes:}


The required amount of each dry mix is placed on a smooth non-absorbent surface and a crater is formed in the center. The amount of mixing water $(\mathrm{W} / \mathrm{S}=0.29)$ as water of consistency has poured into the crater. By the aid of a trowel, the dry cement around the outside of the crater is slightly toweled over the mixture to absorb the water for about one minute then mixing is completed for three minutes by gauging trowel.Stainless steel $\left(2.54 \times 2.54 \times 2.54 \mathrm{~cm}^{3}\right)$ cubic moulds are used for moulding. The cement paste is placed in the moulds into two approximately equal layers. Each layer is compacted and pressed until homogeneous specimen is obtained. After the top layer is compacted, the moulds are then vibrated for few minutes to remove any air bubbles to give a better compaction of the paste. The surface of the paste is smoothes by the aid of thin edged trowel.Immediately after moulding, the moulds are cured in humidity chamber at $100 \%$ relative humidity at constant temperature of $25 \pm 1{ }^{\circ} \mathrm{C}$ for the first 24 hours. The cubic specimens are demoulded and then, cured under tape water until the desired curing time 3, 7and 28 day is reached. After 28 days the cubes are divided into two parts, one immersed in tape water and the other in 5\% $\mathrm{MgSO}_{4}$ solution fordifferent times up to 360 days. The $\mathrm{MgSO}_{4}$ solution is renewed

monthly.

\section{B.3.Stopping of hydration}

Stopping of hydration is carried out for each sample by using about $10 \mathrm{~g}$ of the crushed hardened pastes after doing the compressive strength test put it into a beaker containing $100 \mathrm{ml}$ of acetone / ethyl alcohol (1:1 by volume)(El.Didamony and Khalil,1981). Mixture was stirred for $0.5 \mathrm{hr}$, the residue was filtrated off then washed with ethanol and divided it into two parts,first part dried at $100^{\circ} \mathrm{C}$ and second part dried at $50^{\circ} \mathrm{C}$ for about $24 \mathrm{hrs}$ to make sure of complete removal of humidity. The dried samples were then stored in desiccators for the following physico-chemical analysis, combined water content and X-ray diffraction.

\section{C.Methods of Investigations:}

\section{C.1.Chemically combined water content (Wn \%)}

Two representative samples of each dried hardened plain and blended cement pastes, exactly about one gram of each, were weighed in silica crucibles and ignited for one hour at $950^{\circ} \mathrm{C}$ in adjusted muffle furnace, cooled in desiccator then weighted. The chemically combined water (Wn \%) (i.e. the amount of water retained after drying at 
$100^{\circ} \mathrm{C}$ ) was calculated using the following equation:

$\mathrm{Wn} \%=\left[\left(\mathrm{W}_{2}-\mathrm{W}_{3}\right) /\left(\mathrm{W}_{3^{-}}\right.\right.$

$\left.\left.\mathrm{W}_{1}\right)\right] \times 100$

Where, $\mathrm{W}_{1}$ : the weight of the empty crucible $(\mathrm{g}), \mathrm{W}_{2}$ :the weight of the crucible + sample beforeignition $(\mathrm{g}), \mathrm{W}_{3}$ :the weight of the crucible + sample after ignition $\left(950^{\circ} \mathrm{C}\right) .2 . \mathrm{C} .2$. Compressive strength

A set of the same mix and age of three cubes were used for determination of the compressive strength of the hardened cement pastesASTM Designation: C-150 (2007). The averagevalueof the three cubes considered in $\mathrm{kg} / \mathrm{cm}^{2}$. The strength test machine used in this work was point load taster (D550-Cntrolstype, Milano-Italy).

\section{C.3.X-raydiffractometry}

The formed hydration products are identified by means of X-ray diffraction technique. X-ray diffraction patterns of the samples were recorded by using Philips X-ray diffractometry (PW1390), using $\mathrm{Cu}-\mathrm{K} \alpha$ with nickel filter. Each sample was subjected to X-ray under working conditions of 40 Kilo Volts and 20-milliampers.

\section{Results and discussion}

\section{A. Curing in tape water}

The interpretation of hydration characteristics of Portland cement and its blends with other additives can be investigated by mechanical (compressive strength), combined water (Wn \%), and X-Ray diffraction analysis.

\section{A.1. Compressive strength}

The compressive strength of the various investigated hardened cement pastes in tape water are represented graphically in Figure (4).The results indicate that the compressive strength increases with the increase of curing age, for all mixes. The partial substitution of OPC by slag, SF, and CKD leads to an improvement in compressive strength value as compared with neat OPC. This is mainly due to the reaction of GBFS and SF with the liberated $\mathrm{Ca}(\mathrm{OH})_{2}$ are forming excessamounts of $\mathrm{CSH}$. In general, the hydration of GGBFS in combination with OPC, at normal stage, is a two-stage reaction. Initially, and during the early hydration, the predominant reaction is with alkali hydroxide, but subsequent reactions are predominantly with calcium hydroxide,(Sajedi F. and Abdul razak H.,2010). 


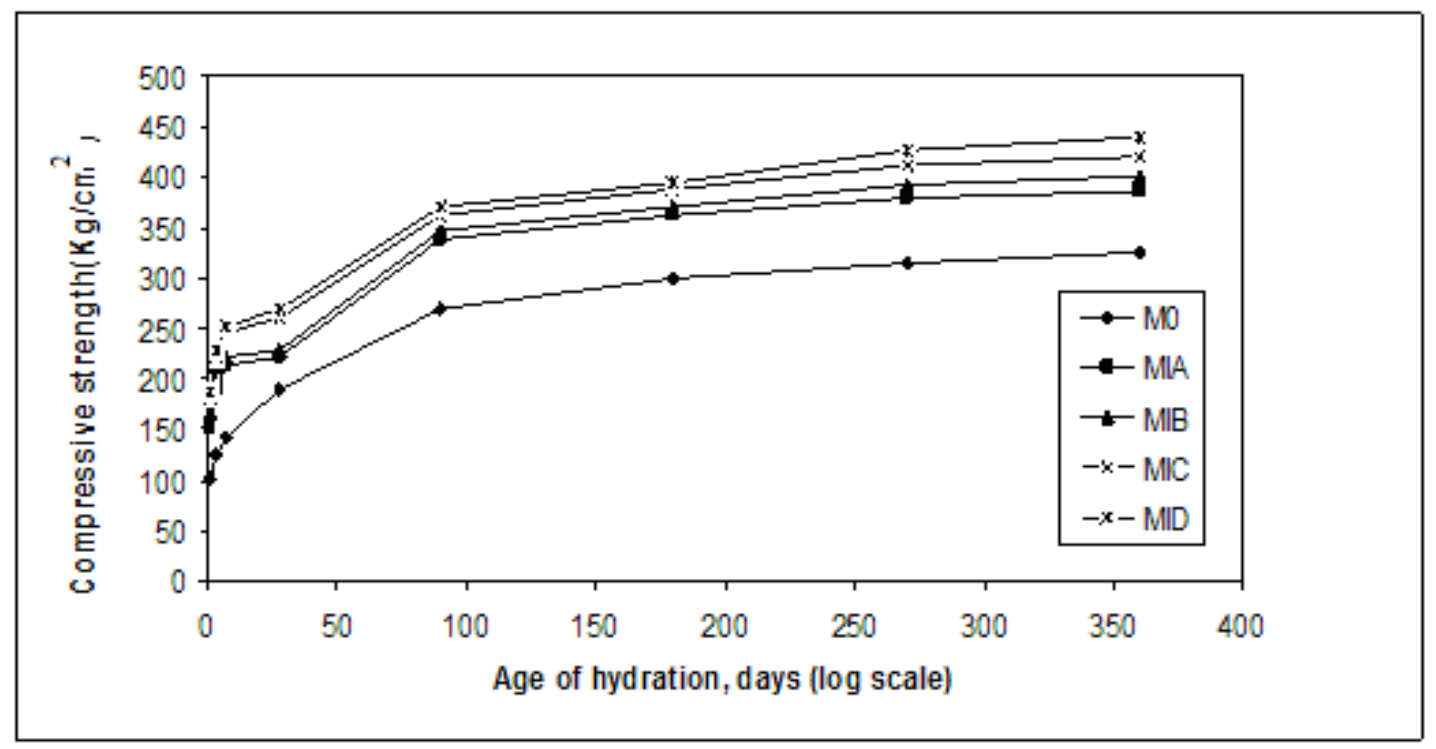

Figure 4: The compressive strength results $\left(\mathrm{kg} / \mathrm{cm}^{2}\right)$ ofdifferent mixes at various hydration ages cured in tape $\mathrm{H}_{2} \mathrm{O}$.

\section{A.2 Combined water}

Chemically combined water is determined to study the progress of the hydration reaction of the different cement pastes. The results of chemicallycombined water content (Wn \%) of the various hardened blended cement pastes compared to the blank paste as a function of the hydration age are represented graphically in Figure (5).

The combined water contentsincrease with increasing hydration time for all the investigated hardened cement pastes. This can be explained as a result of the progress of the hydration reaction of the different cement pastes with increasing time. Also, due to the formation of excess calcium silicate hydrate (CSH). 


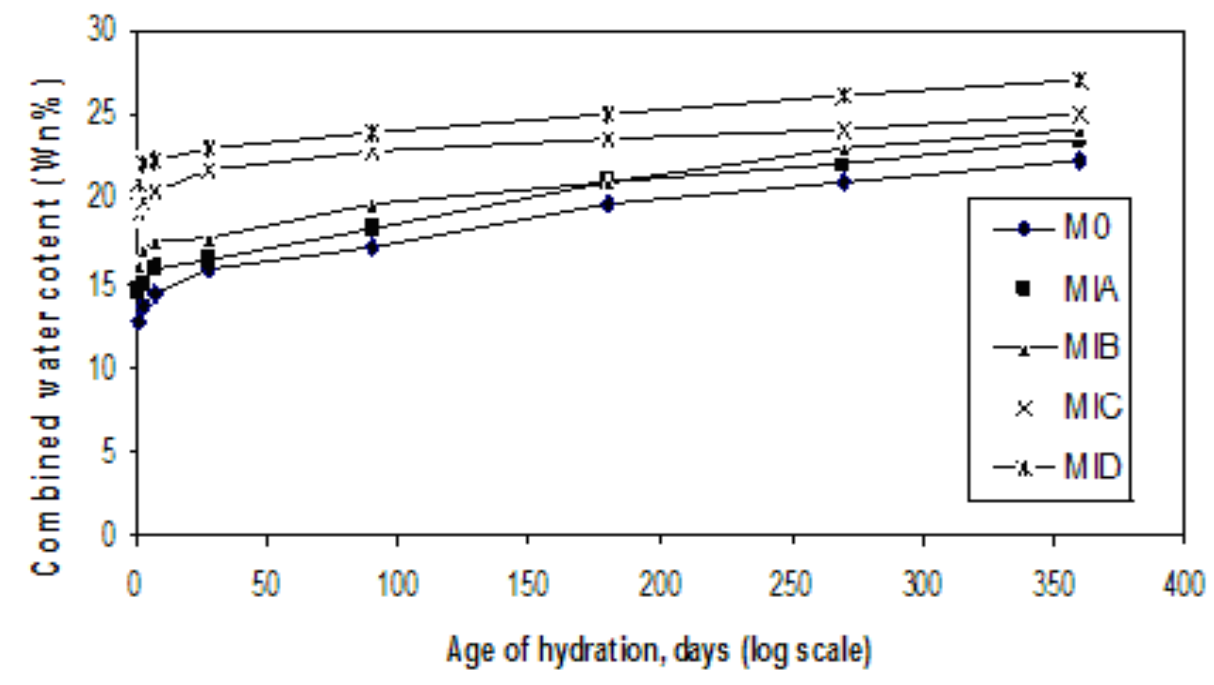

Figure 5: The combined water results (Wn \%) ofdifferent mixes at various hydration agescured in tape $\mathrm{H}_{2} \mathrm{O}$.

\section{A.3. Phase Composition:}

The X-ray diffraction analysis is a useful technique to identify the phase composition of the formed hydration products. Figures (6-10) show the X-ray diffraction patterns of mixes $\mathrm{M}_{0}$, MIA, MIB, MIC, MID hydrated at various ages up to 360 days in water, respectively. The results indicate that there is a continuous increase in intensity of the main peaks characteristic to $\mathrm{CSH}$ and $\mathrm{CH}$ inM $\mathrm{M}_{0}$. On the other side, there is a continuous decrease in the intensity of the peaks characteristic to anhydrate silicate phases $\left(\beta-\mathrm{C}_{2} \mathrm{~S}, \mathrm{C}_{3} \mathrm{~S}\right)$ with hydration age. In the other mixes contained GBFS and SF the $\mathrm{CH}$ contents decrease with time due to its reaction with SF andGBFS forming CSH. 


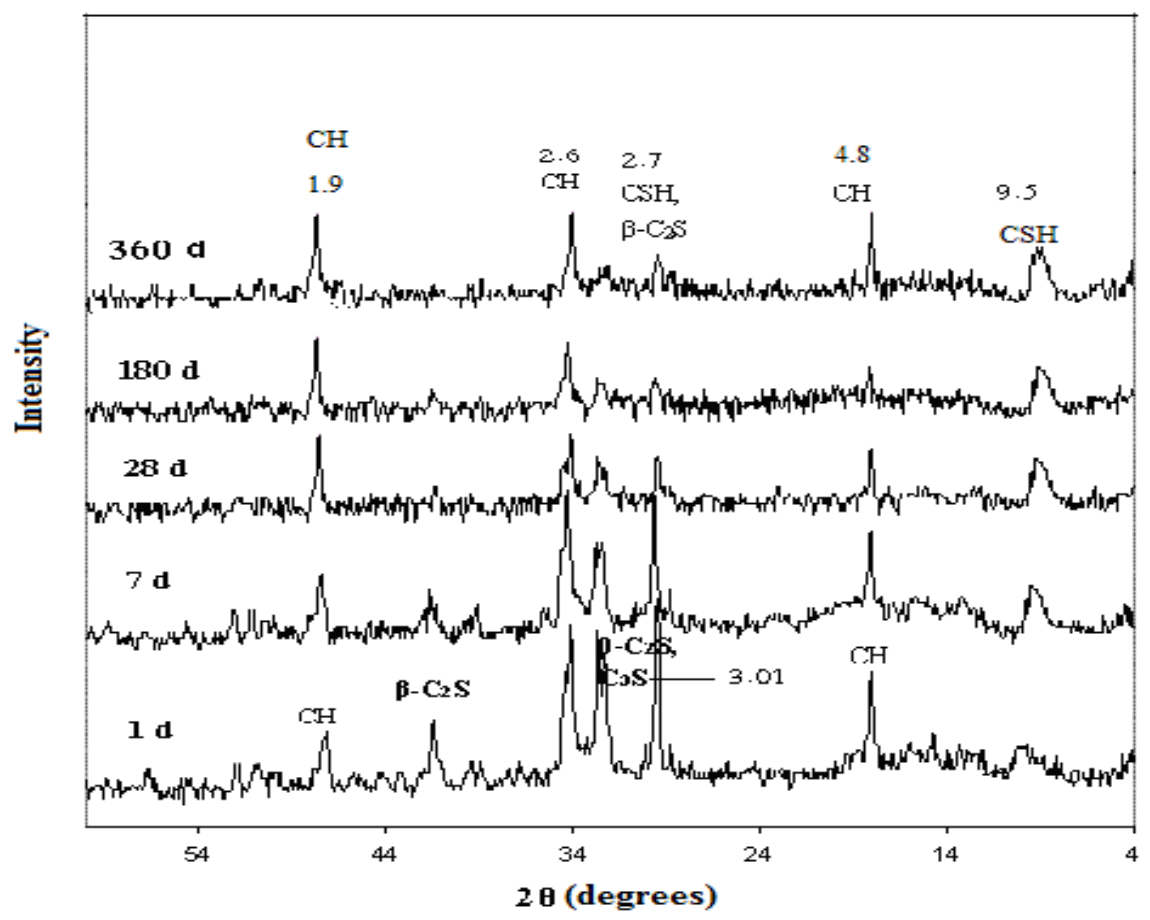

Figure 6: The X-ray diffraction patterns of the hardened Portland cement pastes $\mathrm{M}_{0}$ at various hydration ages cured in tape $\mathrm{H}_{2} \mathrm{O}$.

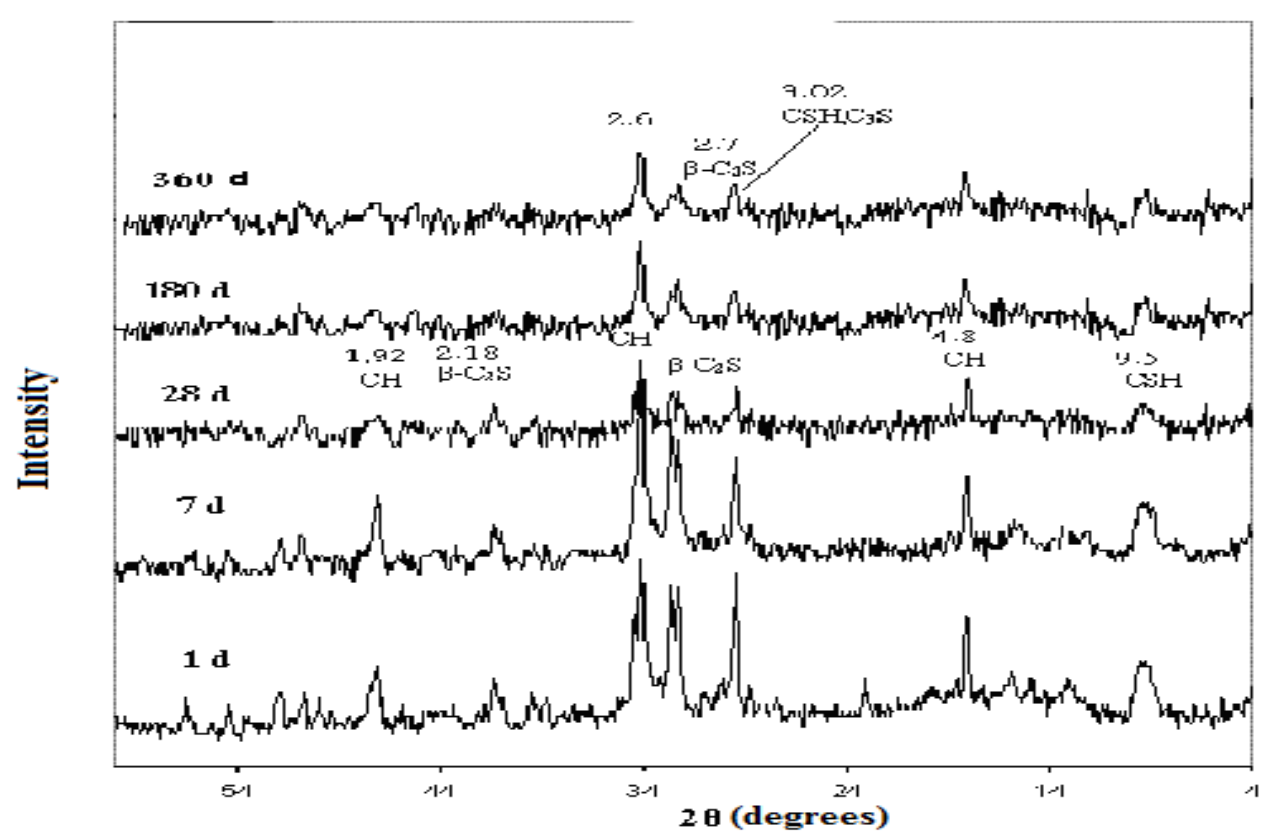

Figure 7: The X-ray diffractionpatterns ofthe hardened Portland cement pastes blendesMIA at various hydration ages cured in tape $\mathrm{H}_{2} \mathrm{O}$. 


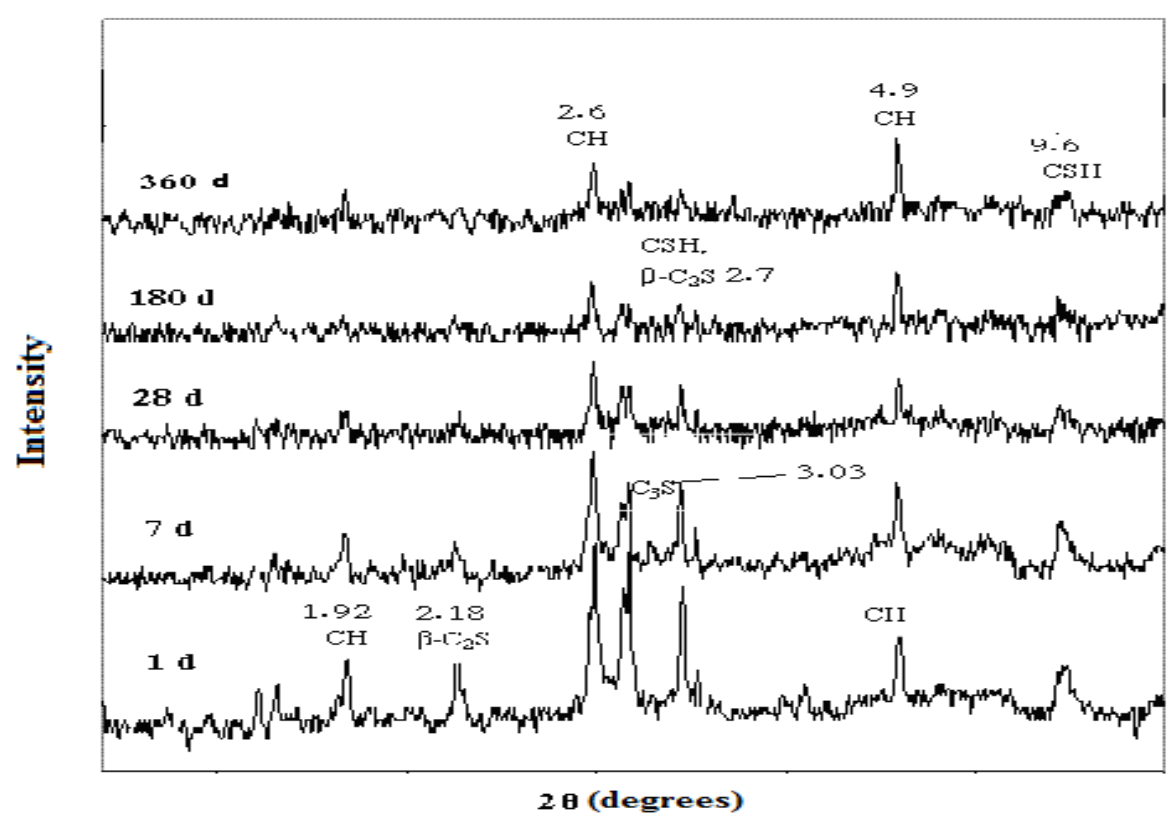

Figure 8: The X-ray diffractionpatterns ofthe hardened Portland cement pastesblendes MIB at various hydration ages cured in tape $\mathrm{H}_{2} \mathrm{O}$.

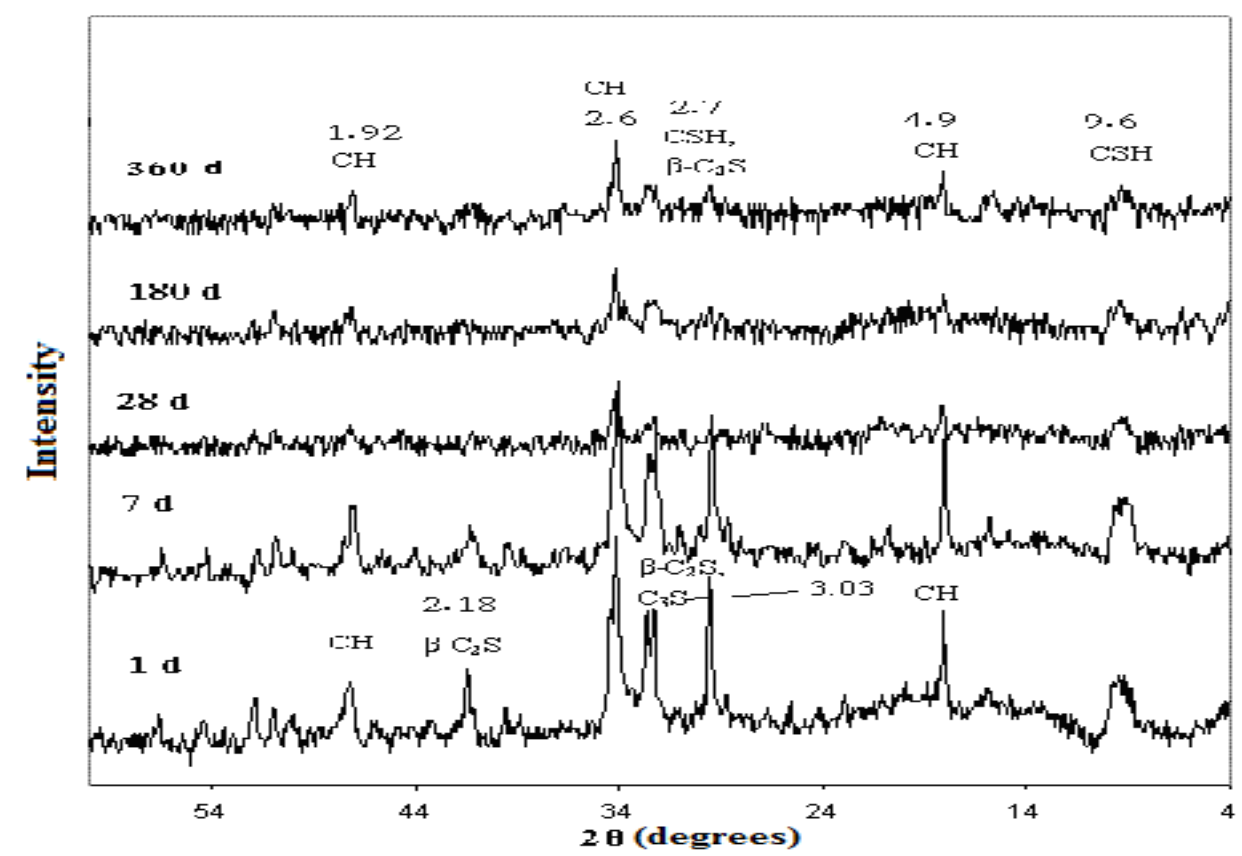

Figure 9: The X-ray diffraction patterns of the hardened Portland cement pastes blendes MIC at various hydration ages cured in tape $\mathrm{H}_{2} \mathrm{O}$. 


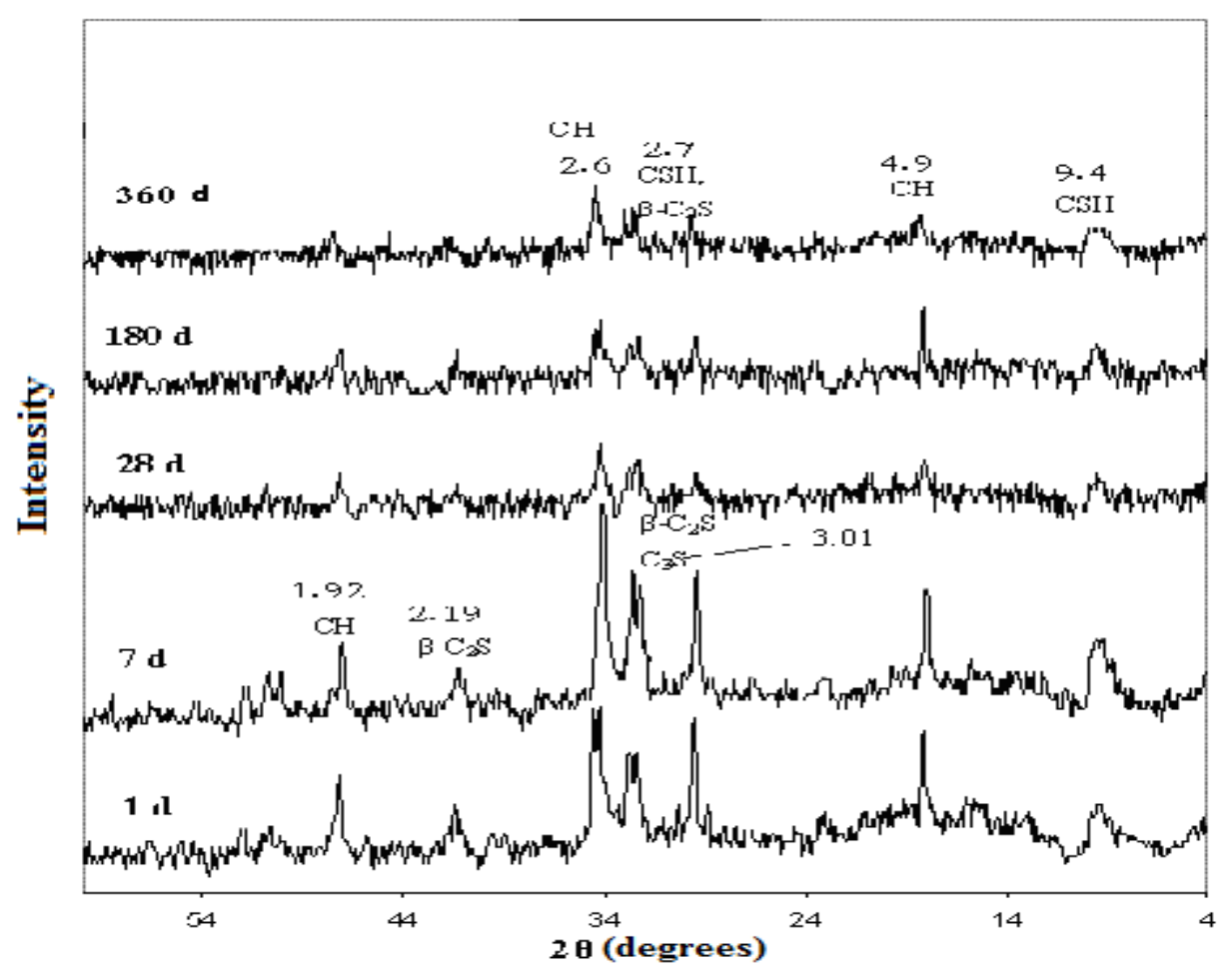

Figure 10: The $\mathrm{X}$-ray diffraction patterns of the hardened Portland cement pastesblendes MID at various hydration ages cured in tape $\mathrm{H}_{2} \mathrm{O}$.

\section{B.Curing in $5 \% \mathrm{MgSO}_{4}$}

\section{B.1. Compressive strength}

The Compressive strength of the systemM $\mathrm{M}_{0,}$ MIA, MIB, MIC and MID cured in $5 \% \mathrm{MgSO}_{4}$ are represented graphically in Figures (11).Curing the hardened cubes of these systems in5\%, $\mathrm{MgSO}_{4}$ improve the compressive strength and the bulk densitydue to the precipitation of calcium sulfate in the pores of the hardened pastes and then decrease till 360 days. In addition, the presence of SF helps in increases the bulk density and the compressive strength.

While in case of net cement $\left(\mathrm{M}_{0}\right)$ the compressive strength increase in the early ages due to the reaction of $\mathrm{MgSO}_{4}$ with $\mathrm{CH}$ forming $\mathrm{CaSO}_{4}$ which precipitate in the pores, so decrease the porosity and increase the bulk density and compressive strength. At latter ages, the sulfate reacts with $\mathrm{C}_{3} \mathrm{~A}$ forming ettringite, which make cracks.In addition, $\mathrm{SF}$ reacts with the liberated $\mathrm{CH}$ forming $\mathrm{CSH}$, which improve the compressive strength. 


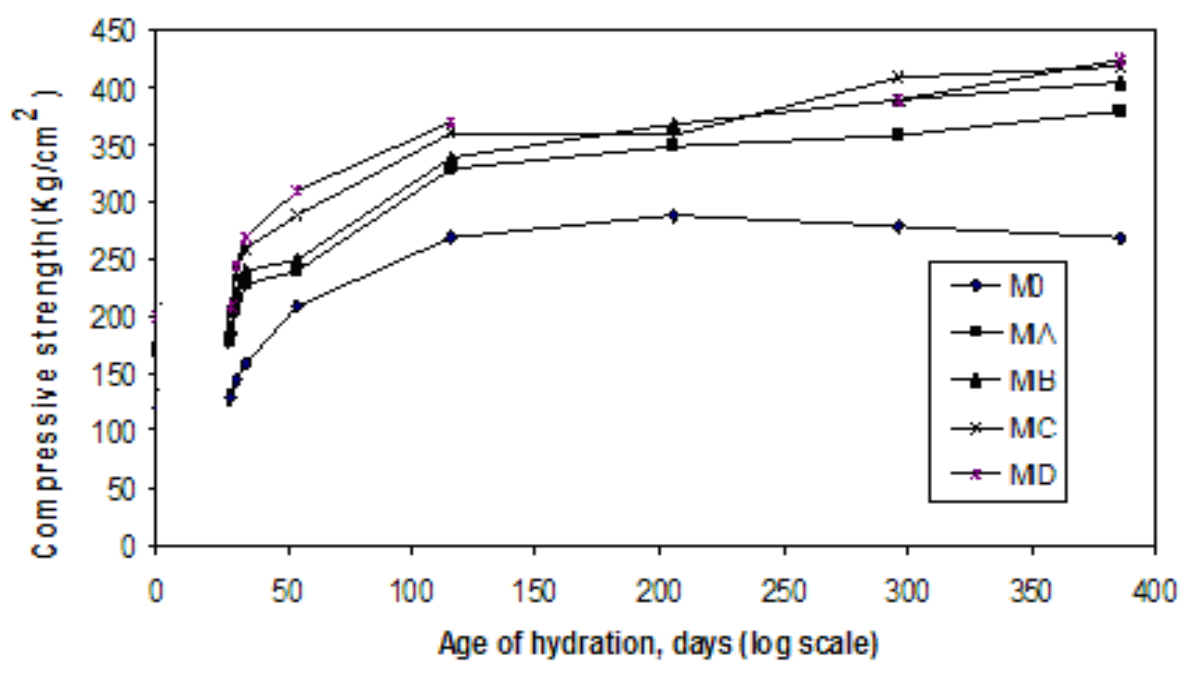

Figure 11: The compressive strength $\left(\mathrm{kg} / \mathrm{cm}^{2}\right)$ resultsof mixes at various hydration agescured in $5 \% \mathrm{MgSO}_{4}$.

\section{B.2. Combined water}

Curing of the hardened cubes of the different mixes in $5 \% \mathrm{MgSO}_{4}$ improve thecombined water and show continues increase in the combined water content as a result of the progress of the hydration reaction of the different cement pastes with increasing time for all the investigated hardened cement pastes whichare represented graphically in Figure (12).

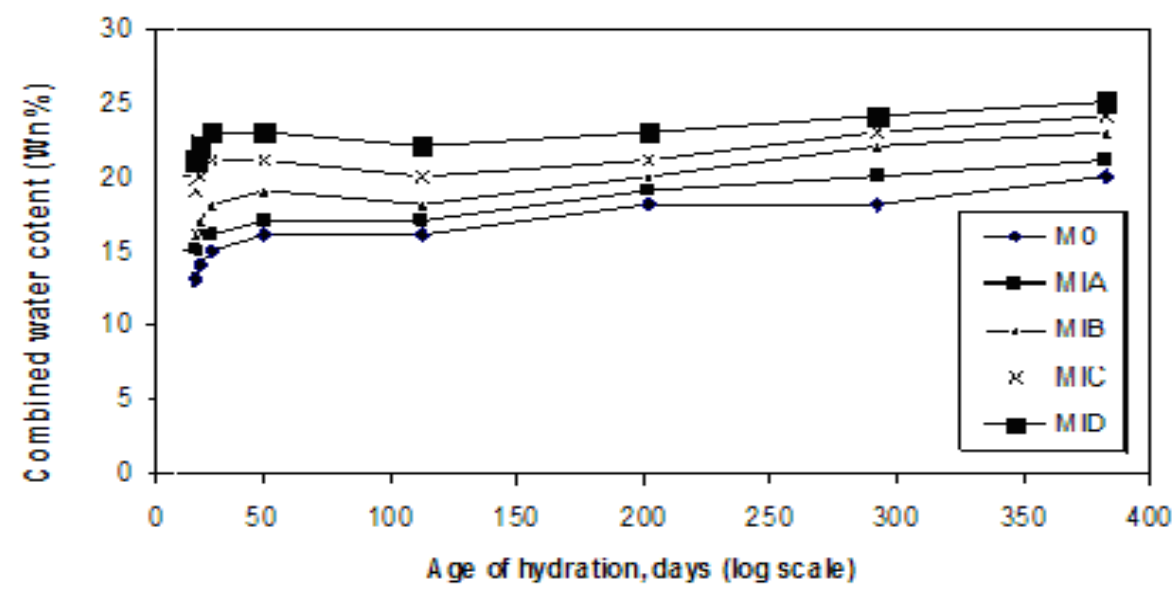

Figure 12: The combined water (Wn \%) results of mixes at various hydration ages cured in $5 \% \mathrm{MgSO}_{4}$. 


\section{B.3. Phase Composition:}

Figures (13-17) show the X-ray diffraction patterns of mixes $\mathrm{M}_{0}$, MIA, MIB, MIC, MID hydrated at various ages up to 360 days cured in $5 \% \mathrm{MgSO}_{4}$, respectively. The results indicate that there is a continuous increase in intensity of the main peaks characteristic to CSH. Moreover, appearanceof ettringite peaks, and this is due to the reaction of $\mathrm{SO}_{4}^{-2}$ with $\mathrm{C}_{3}$ Aand its hydrate forming ettringite (E) which make cracks. And the reaction of $\mathrm{CH}$ and $\mathrm{MgSO}_{4}$ which producescalcium sulphate and magnesium

hydroxide.

$$
\mathrm{Ca}(\mathrm{OH})+\mathrm{MgSO}_{4} \rightarrow \mathrm{CaSO}_{4}+\mathrm{Mg}(\mathrm{OH})_{2}
$$

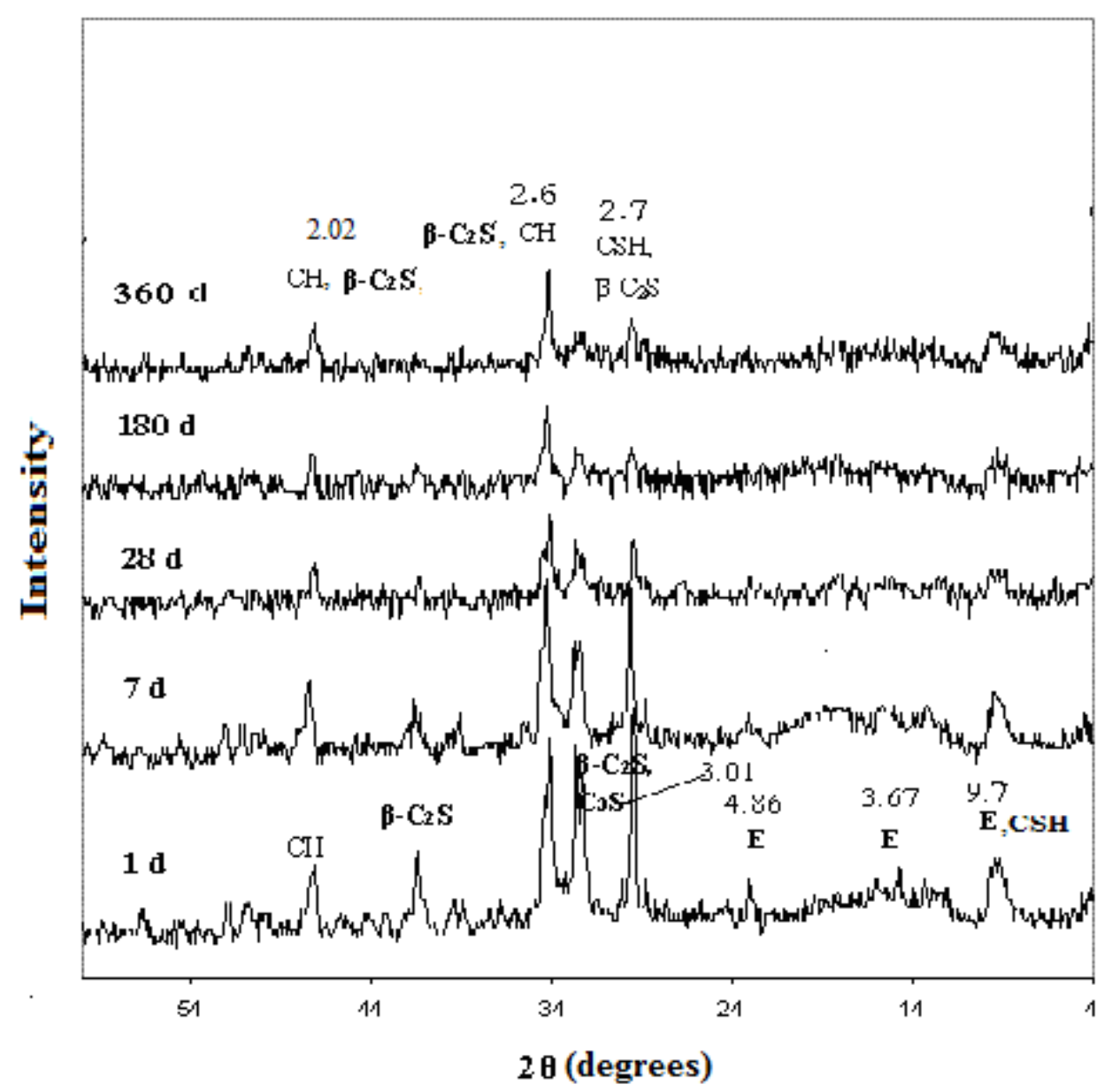

Figure 13: The X-ray diffraction patterns of the hardened Portland cement pastes $\mathrm{M}_{0}$ at various hydration ages cured in $5 \% \mathrm{MgSO}_{4}$. 


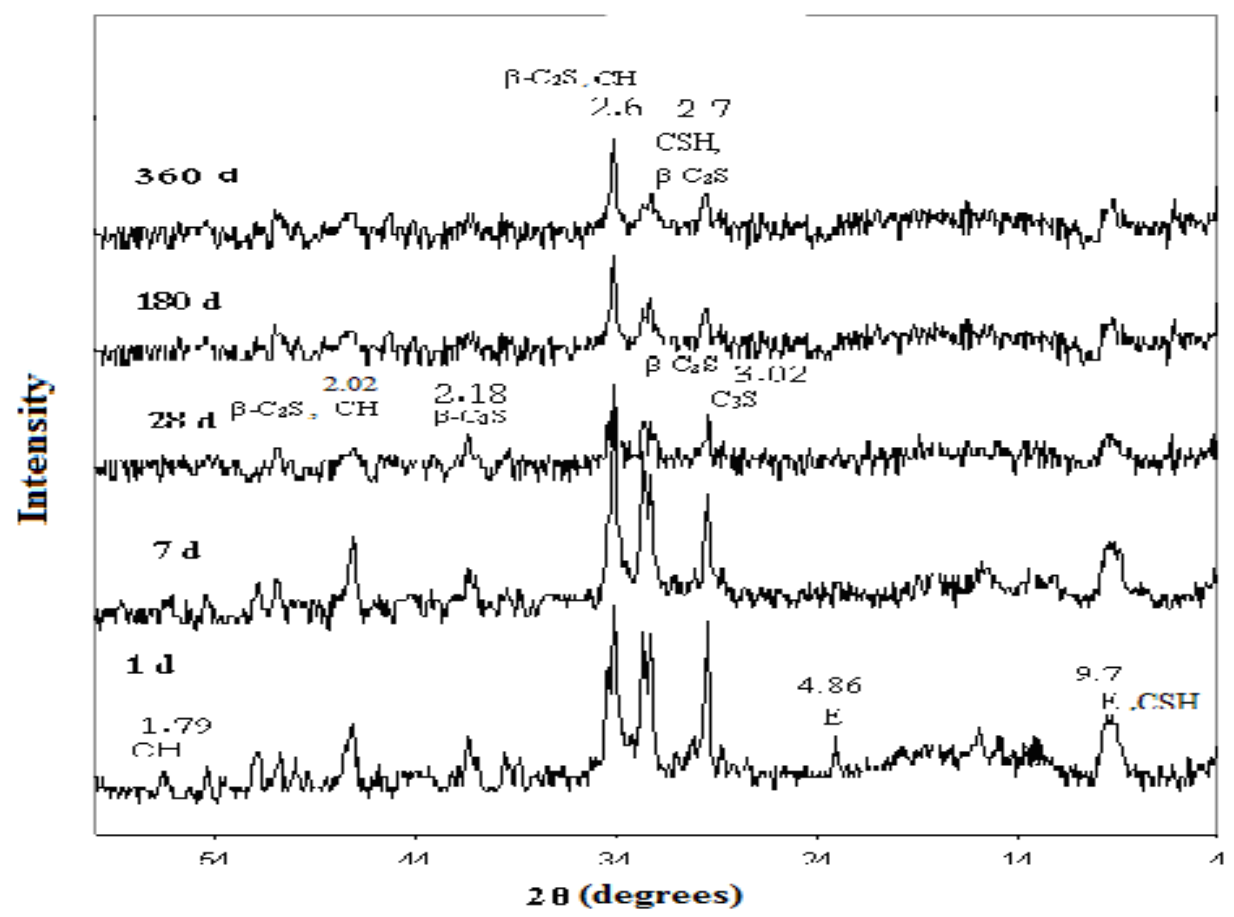

Figure 14: The X-ray diffraction patterns of the hardened Portland cement pastesblended MIA at various hydration ages cured in $5 \% \mathrm{MgSO}_{4}$.

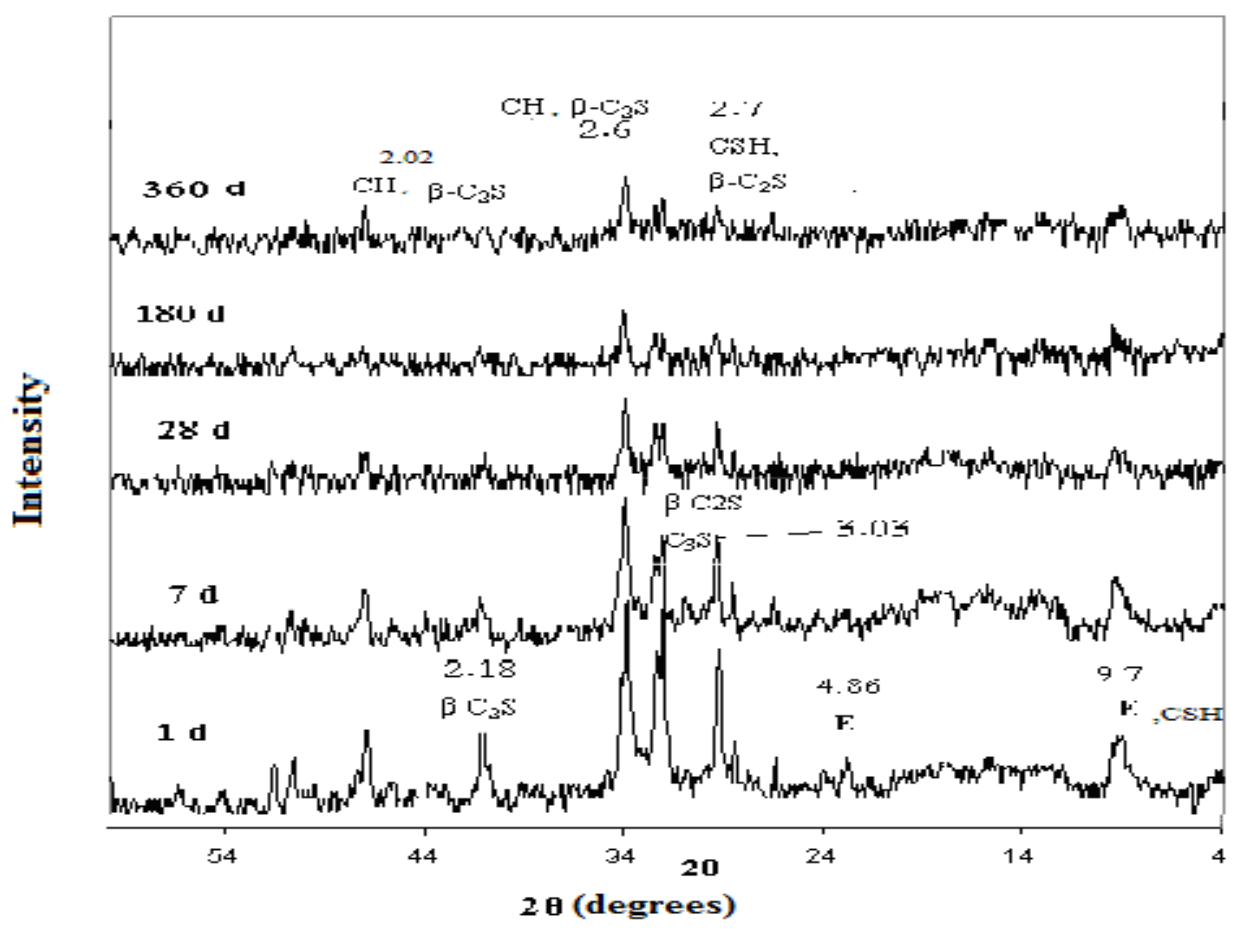

Figure 15: The X-ray diffractionpatterns ofthe hardened Portland cement pastesblended MIB at various hydration ages in $5 \% \mathrm{MgSO}_{4}$. 


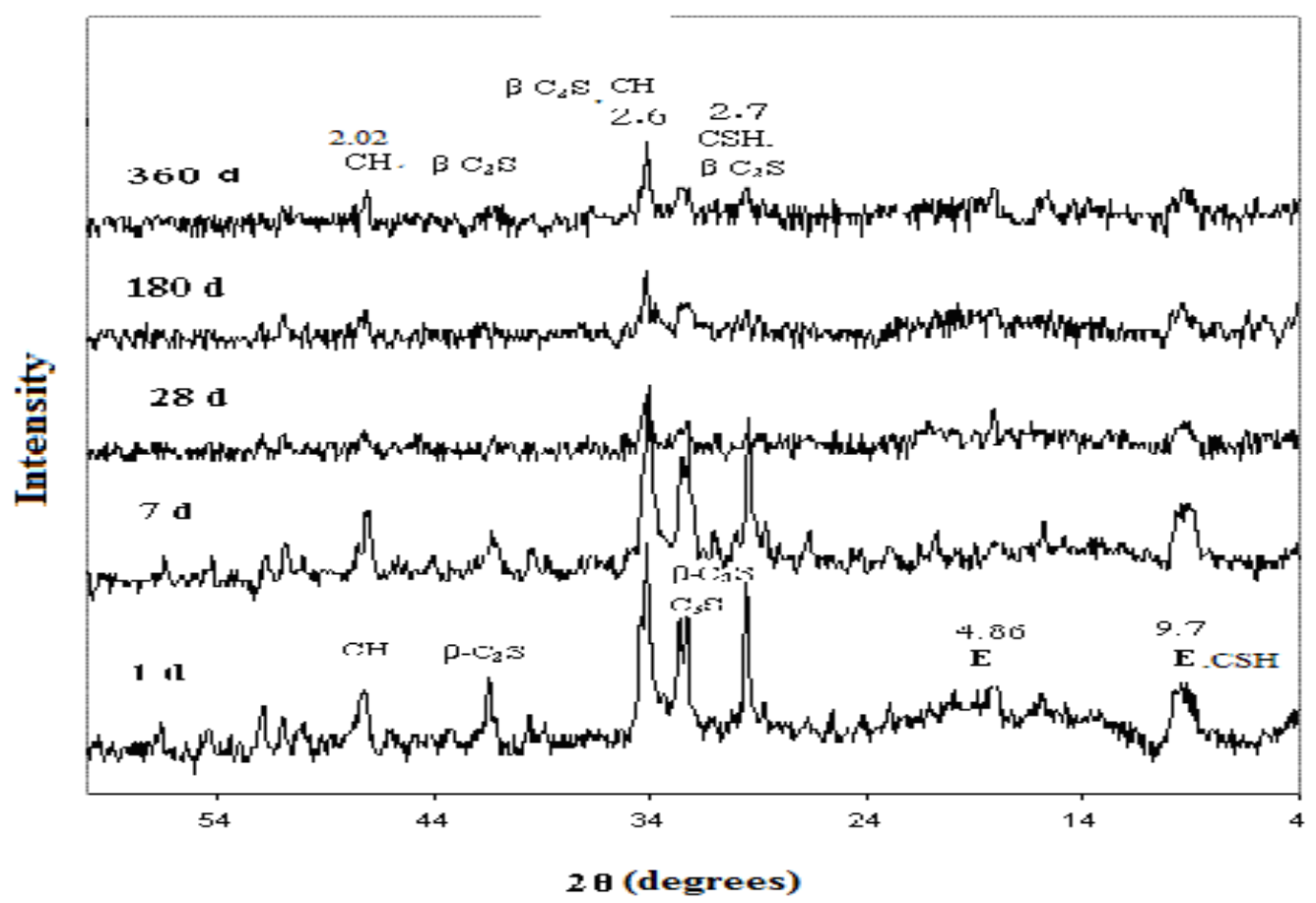

Figure 16: The X-ray diffraction patterns of the hardened Portland cement pastesblended MIC at various hydration ages cured $5 \%$ inMgSO 4 .

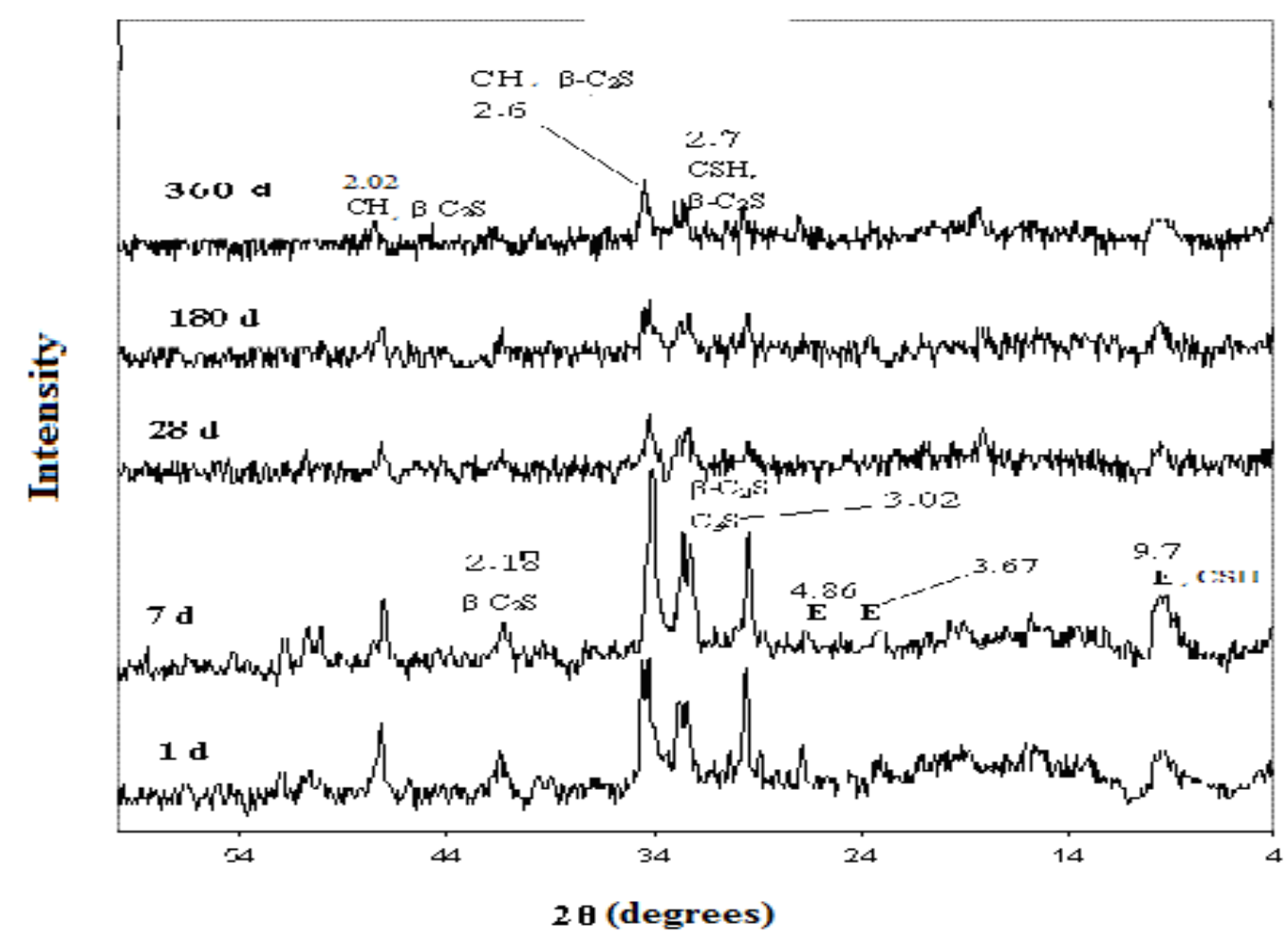

Figure 17: The X-ray diffraction patterns of the hardened Portland cement pastesblended MID at various hydration ages cured in $5 \% \mathrm{MgSO}_{4}$. 


\section{Conclusion:}

Sulphae attack on cement pastes causes a serious deterioration. The damage usually starts at edges and followed by cracking.

Magnesium sulphate has a more damage effect than other sulphates because it leads to the decomposition of the hydrated calcium silicate as well as $\mathrm{Ca}(\mathrm{OH})_{2}$ and of hydrated calcium aluminates.

All the hardened blended cement pastes showed an increase inchemically combined water content by increasing the hydration age. This indicates the progress of the hydration reaction with age of hydration.

The hardened cement pastes blended with CKD, SF, and Slag showed an increasein compressive strength than the neat Portland cement (OPC)paste. The increase in compressive strength is due to the continues hydration reaction of anhydrated cement components to form more hydration products in addition to the reaction of $\mathrm{CKD}, \mathrm{SF}$, and Slag with the liberated $\mathrm{CH}$ to form more $\mathrm{CSH}$ leading to increase compressive strength.

The main hydration products formed by hydration of cement paste (OPC) and blended cement pastes are calcium silicate hydrates (CSH) and calcium hydroxide $(\mathrm{CH})$ in addition the peaks characteristic to calcium carbonate $\left(\mathrm{Cc}^{-}\right)$were identified.

All the hardened blended cement pastes especially MID containing (50\% OPC, $5 \% \mathrm{CKD}, 25 \%$ Slag, and 20\% SF) showed the highest result inchemically combined water content. This indicates that the progress of the hydration reaction with age of hydration. In addition, MID also showed the highest resultin compressive strength than the neat Portland cement (OPC) without any additives and also the otherblends (MIA, MIB, MIC). 


\section{References}

1. Abdel Rahman A., Abo-El-Enein S. A., Aboul-Fetouh M., and Shehata Kh., "Characteristics of Portland blast-furnace slag cement containing cement kiln dust and active silica", Arabian Journal of Chemistry, 29, 10-1016, (2011).

2. ASTM Destination: C-150, " Standard test method for compressive strength of hydraulic cement ",ASTM standards,(2007).

3. Chen W., and Brouwers H. J. H., "Alkali binding in hydrated Portland cement paste", Cement and Concrete Research, 40, 716-722, (2010).

4. EL-Didanomy; H., Khalid; A. A.,"Investigation of the hydration products of the system $\mathrm{CaO}-\mathrm{Al}_{2} \mathrm{O}_{3}-\mathrm{SO}_{3^{-}} \mathrm{SiO}_{2}$ in presence of raring amount of $\mathrm{SiO}_{2}$ ", Zement- Kalk - Gips Vol. 34, PP 660-663, (1981).

5. Mathias Maes and Nele De Belie "Resistance of concrete and mortar against combined attack of chloride and sodium sulphate"Cement \& Concrete Composites 53, 59-72,(2014).

6. Pavia S., and Regan D., "Influence of cement kiln dust on the physical properties of calcium lime mortars", Mater Struct, (43), 381-91,(2010).

7. Pardhasaradhi .K, Giri Prasad .G "Investigation on Hardened properties ofConcrete with Silica fume as Partial Replacement of Cement"5(2), 23476710, (2016).

8. SajediF., Abdul razak H. "The effect of chemical activators on early strength of ordinary Portland cement-slagmortars" Construction and Building Materials 24, 1944-1951, (2010)

9. Svinning K., 'Design and manufacture of Portland cement-application of sensitivity analysis in exploration and optimization Part I: Exploration", Chemometrics and Intelligent Laboratory Systems, 8(4), 177-187, (2006).

10. Inan Sezer Gozde "Compressive strength and sulfate resistance of limeston and/or silica fume mortars"Construction and Building Materials 26, 613$618,(2012)$.

11.Wang Q, Peiyu Yan, Guidong Mi "Effect of blended steel slag-GBFSmineral admixture on hydration and strengthof cement"Construction and Building Materials $35,8-14,(2012)$. 
تأثير بعض المخلفات الصناعيه على الخواص القيزيوكيميائيه والميكانيكيه لعجائن الاسمنت المتصلده

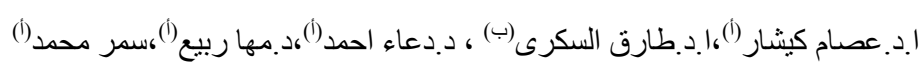

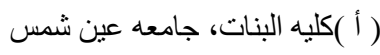

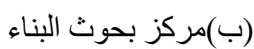

الاسمنت المخلوط هو تكنولوجياجديدة تتضمن خلط نسب من الاسمنت البورتلاندي مع موا

معدنيةآخرى مطحونة مثل خبث الحديد و غبار السيليكا وغير ها. وقد نالت هذه التكنولوجيا اهتمامًا متز ايداً منذ القرن الماضي وذلك لفو ائدها الاقتصادية و البيئية المتعددة.ويعتبر خبث الحديد و غبار السيليكا من المو اد البوزو لانية النشطة التي من المنوقع أن تتميز بخو اص تأدرت عاليه ومن ثم تم استخدامه في هدا البحث.

و المو اد المستخدمة في هذه الدراسة هي أسمنت بو رتلاندي عادي وخبث الحديد و غبار السيليكا و تراب

افران الاسمنت و تم تحضير مجموعات من الاسمنت المخلوط و قد تم دراسة الخواص الفيزيوكيميائية و الميكانيكية للعجائن الاسمنتية المختلفة وذللك بعد الخلط بالماء ، و الكبس ثم الغمر في الماء بعد حفظ العينات في جو رطب ( 100\%) في اليوم الأول ، وقد تم دراسة التغيير في الخصائص الفيزيقوكيميائية والميكانيكية للعجائن المتصلةة عند أزمنة 1,3 ، 7 ، 28 ، 90,180، 270، 260 يوم من المعالجة تحت الماء .

تم در اسة ومتابعة نشاط التأدرت لجميع ال عجائن في هذه الدراسة وذللك بقياس مقاومة تحمل الضغط

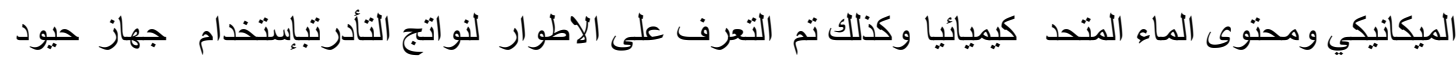

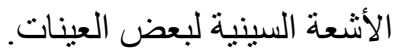

وكذلك تم در اسه تاثثير محلول كبريتات الماغنسيوم ( 5 على الخو اص الميكانيكيه للخلطات المختلفه لعجائن الاسمنت المخلوط المتصلده.

وأهم النتائج التي أمكن التوصل إليها يمكن تلخصيها فيما يلي: • أظهرت نتائج المخلوط المحتوية على 25\% خبث الحديج و 20\% غبار السيليكا و 5\% تراب افران مقاومة تحمل كبيرةللضغط الميكانيكيعن الاسمنت الغير مخلوط.

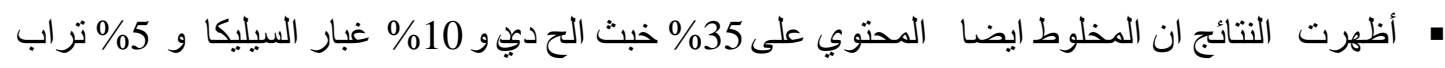
افران مقاومة تحمل كبيرةًلضغط الميكانيكي عن الاسمنت الغير مخلوطلكن اقل من النسبه السابقه. • أظهرت النتائج ان المخلوط المحتوي على 5\% خبث الح دبيّ 5\% غبار السيليكا و 40\% تراب افران مقاومة تحملاقللضغط الميكانيكي عن الاسمنت الغير مخلوط. كما أظهرت النتائج ان معظم المخاليط المحتوية على 5\%تراب افران الاسمنت و5و10و20\% غبار السيليكا و و25و35و40\% خبث حديد الموجود فمحلول كبريتات الماغنسيوم ( 5 مقاومة تحمل كبيرة للضغط الميكانيكي عن الاسمنت الغير مخلوط ـوذلك نتيجة لتفاعلات الهيدره وملئ الثغر ات الموجوده بالاسمنت. 